\title{
PREFACE. Where We Are Going: Presidential Management and the External Presidency
}

THIS BOOK IS ABOUT Lyndon B. Johnson's role as president in handling foreign policy. It views that role primarily in terms of his contacts with other U.S. officials through whom he worked and the processes he employed to decide upon policy and see through its implementation. It deals in this particular sense with the presidential administration of foreign relations, but it is not a conventional, descriptive administrative study. It is an exploratory venture. The ideas that it applies are unfinished. This brief chapter explains why and tells the reader what to expect.

It is now more than thirty years since Richard Neustadt broke new ground in his book Presidential Power: The Politics of Leadership. ${ }^{1}$ Neustadt showed us that the presidency must be understood in terms of the wholeness of the president's role, the combination of constitutional and political powers and functions that the American presidency encompasses, a wholeness that is much greater than the sum of its parts. ${ }^{2}$

The implications of Neustadt's explanation of presidential leadership and action for the internal workings of the American political system are profound. They have influenced a generation of scholarship on the presidency and directly influenced at least one president. Their effect has been to enhance the general quality of scholarship on the presidency. This has been the case primarily with respect to the internal presidency. By this I mean the president's struggle to be master of the executive branch with the Congress and the public. Neustadt's thesis about presidential leadership and power has been less well understood and less applied with respect to American foreign relations and policy, when the president attends to the formation and implementation of policies dealing with foreign governments and other organizations external to the United States, which is the subject of this book. This neglect of the external presidency can be laid in part to the discrediting of the external presidency as a 
result of Lyndon Johnson's handling of Vietnam, but it also reflects difficulties with the employment of contemporary ideas about democratic leadership.

Students of the internal presidency have been able to proceed on the basis of a more widely accepted set of political values than students who address the external presidency. Nowhere is this problem better illustrated than with respect to Neustadt's own work. He himself expanded the foreign relations aspect of his own interests in Alliance Politics, an influential little volume which he published in I970, but in doing so he did little to advance his earlier pioneering inquiry into presidential power and leadership. He virtually ignored the issue of the president's unique situation, which he had developed in Presidential Power. He pursued, instead, a less controversial theme which he had employed in that book-that of pluralistic government, a grouping of interests that contend and cooperate with one another. In this later work he attended to the impediments to cooperation at the expense of one of the central themes of Presidential Power, the implications of contention and conflict. Neustadt published a revised edition of Presidential Power in 1980 and another in 1990 which included new material. Neither broke new ground to explore the external presidency. ${ }^{3}$

Alliance Politics is a cautionary tale about the difficulties of bilateral cooperation between the United Kingdom and the United States. Its message comes through with increasing force as Neustadt spreads before the reader the obstacles to Anglo-American understanding which he found at the interface between officials in "Whitehall" and the "White House" and beyond. It leads to Neustadt's final point, that managing relations with other governments is very difficult to get right, which he makes with a revealing personal reference.

The pluralist concept of politics and even of government is of a marketplace of competing interests that distribute power and other political valuables. It has been a serviceable and popular justification for internal politics in the United States, including the functioning of the presidency. It has served to reconcile presidential power and action to internal democratic ends and procedures. One way it has reconciled them has been to show that the president is less powerful than he appears to be, a thesis which Neustadt adopted and employed to great advantage. Pluralism has not been as popular or successful in reconciling with democratic norms the presidency's employment of presidential power and action in external relations, not at least as Presidents Johnson and Nixon exercised power externally in the sixties and early seventies. 
In the period that Neustadt's work spans-from the mid-fifties to the late sixties-the president's conduct of foreign relations came under serious attack. Neustadt experienced that attack directly and personally. When Presidential Power was first being widely read, at the beginning of the sixties during the Kennedy administration, Neustadt was a professor at Columbia University. At that time, the reaction of his academic colleagues to his extraordinary access to President Kennedy, to the extent that they knew about it, was similar to their reaction to other academics with access to the president. It was mostly favorable because its consequences seemed largely favorable. The new status which academics had attained in Washington boosted the status of universities.

At the end of the sixties the situation had changed dramatically. American university faculties, in a widespread change in attitudes, had become alienated from the presidency. As a senior professor at the Kennedy School of Government at Harvard, Neustadt himself would have encountered suspicion and hostility on the Harvard campus toward faculty members or anyone else who had been involved with the Johnson White House or was involved with the new Nixon administration.

Neustadt's Alliance Politics reflects this change of mood about the presidency. In it he analyzed two historical episodes involving crises in Anglo-American relations in which the American president's role was central. The first involved Eisenhower. It was the crisis in Anglo-American relations precipitated by Britain's participation with France and Israel in the Suez War against Egypt in 1956. The second involved Kennedy. It was the crisis generated by the cancellation of the development of the American airborne missile, Skybolt, which the British were counting on to deliver their nuclear weapons. Neustadt described the Anglo-American alliance as an exceptionally close, tightly knit relationship between two governments and governing societies bound with strong networks of personal friendship. Despite close relations between these two political communities, indeed, arising out of them, he found in both crises intricate misperceptions, misunderstandings, and misassessments by officials in each government of officials in the other which, in turn, produced serious missteps in their cooperative dealings. In both cases, on both sides of the Atlantic, government officials took actions which harmed their friends on the other side unintentionally and harmed their common interests.

The Suez and Skybolt cases provided an excellent opportunity for Neustadt to examine his thesis about holistic presidential power and the the uniqueness of the president's role, a thesis which had im- 
mediately become influential when he introduced it eight years earlier. He might have used these cases to push on and apply his thesis to the nurturing and protection of presidential power in dealings with allies. He did not. He focused mainly on the impediments to cooperation between the two governments without special reference to presidential power.

Eisenhower's diplomacy during the Suez crisis could have provided a solid vehicle for examining presidential power. Eisenhower had been the main foil, or negative model, for Neustadt's development in the I950s of his ideas about the necessity for presidential leadership which required the president to exploit the assets of his office in the competitive struggle of American politics. Eisenhower, in Neustadt's view at the time, had usually not understood this rule. Neustadt could have employed the Suez case to take himself back to his first judgments about Eisenhower and therefore to the roots of his thesis about presidential power. But he did not.

Writing more than a decade later, Neustadt was positive in his appraisal of Eisenhower's behavior in the Suez case. In some respects he even anticipates the new appreciation of Eisenhower's presidency which occurred in revisionist writings in the eighties. (These are discussed briefly in Chapters 6 and 7.) The structured, directive style which Eisenhower employed in dealing with his Secretary of State as well as with others in the Suez case, and which he employed in conjunction with presidential restraint, now appealed to Neustadt. They had not when he wrote Presidential Politics in the late fifties, nor did they in 1963, when he testified before Senator Henry M. Jackson's Subcommittee on National Security Staffing and Operations of the Senate Committee on Government Operations. ${ }^{4}$

The conduct of the British and French, in secretly planning, in cooperation with Israel, to attack Egypt in order to recover control over the Suez Canal, and then in attacking it without consulting the United States, was intended to force Eisenhower's hand. Yet both governments depended heavily on the United States economically and militarily. If Eisenhower had simply acquiesced in their attack once it was underway, Britain and France would be setting the terms of American support for them. If, as they evidently hoped, he would go further and actively cooperate with their attack, the United States would be vulnerable to other embarrassing, hand-forcing, faits accomplis. He would have encouraged them and other American allies and client states to draw, or try to draw, the United States into other ventures which it would not have approved in advance. What would the British and French do next in the knowledge that the United States could be induced to go along? What would other 
powers do if they learned from the Suez War the lesson that they, too, could trap Washington into doing what they could not persuade Washington beforehand to do?

It was an embarrassing moment for all concerned. The formalities of NATO cooperation depicted it as an association of sovereign equals, but they were not all equal. There were small powers like Belgium and Denmark and medium powers like Britain and France, and then there was a superpower, or hegemon, the United States. Sometimes the hegemon got out in front, as it had with the Marshall Plan or the defense of Korea, declaring its intention and challenging other states to come along. In the case of the Marshall Plan, it was Western Europe and the Soviet Union that the United States as the hegemonic power had challenged. In the Korean case, it was the U.N. If NATO members were equal, then the British and French could likewise act and challenge. Suez was in this respect a moment of truth. Eisenhower would not go along. Had he gone along, American hegemony would have been transformed from an order setter for the North Atlantic Alliance into a license for smaller powers to trap the United States into doing their business on their terms, from a source of order to a source of chaos. The implications for presidential power would have been commensurately profound.

These were the issues at stake when Eisenhower forced London and Paris to back down from their attack. To explore these issues when Neustadt examined the Suez crisis at the end of the sixties would have been to push on into external relations the inquiry which he had begun ten years earlier in the nurturing and protection of presidential power.

Did Eisenhower, in standing down the British and French, understand these stakes for American power and for his presidency? The answer is very important. It is also not obvious, and Neustadt did not attempt to provide it. It would have required examining the harder side of Anglo-American relations where national interests were in virtual conflict. Suez posed an issue of alliance discipline which was embarrassing to explain yet essential to deal with from the standpoint of American interests. It posed as well as has any single incident in the postwar era the question of how unique was presidential power in international affairs. The Neustadt of Presidential Politics would have penetrated this thicket in order to explore the president's role as political leader in the face of political interest rivalry and pressures from below to entrap him. Ten years later the Neustadt of Alliance Politics did not.

Although it was less powerful for this purpose, the Skybolt case could also have served as a convenient vehicle for inquiring about 
the external dimensions of presidential power. It could have served Neustadt himself particularly well in that pursuit because he had special, direct knowledge about presidential power in this case. Kennedy had embraced Neustadt's ideas about the presidency at the beginning of his administration, even recommending Presidential Politics to Oval Office visitors. On the basis of the book, he drew Neustadt into a singular role in the White House staff. Neustadt learned the Skybolt story on an assignment from the president. No case writer has had better sponsorship or access! Later, when Neustadt lectured and then wrote about Skybolt, he had an opportunity to inquire into how a president who shared his views about presidential power actually employed it.

Skybolt could have served an inquiry about the differences in interest between the president and his staff as they dealt with the British. For instance, Neustadt described how Kennedy came to recognize what his subordinates were all too slow to recognize (or denied), that there was a serious conflict with the British over Skybolt, which he took it upon himself to resolve. This was a good start on the subject of Anglo-American conflict over Skybolt-actual conflict, not simply misunderstandings. It could have been approached by inquiring about intentional conflictive behavior on both sides. Had Neustadt been interested in the harder side, in addition to his interest in the unintended obstacles to cooperation, he could have gone on to probe the extent of dissembling and deception at the Cabinet level and lower in both countries.

These very issues were raised by a report that had been published by Henry Brandon, a distinguished British journalist assigned to Washington, whom Neustadt knew well. Brandon had reported that a Royal Air Force Group Captain assigned as liaison to the Pentagon was thoroughly informed about McNamara's plans to cancel Skybolt and kept his contacts in Whitehall informed about them. ${ }^{5}$ Brandon's claim, whether true or not, raises at least two questions. One is whether British officials in London feigned ignorance or incomprehension or misperception to hide their foreknowledge of the impending cancellation of Skybolt, and therefore proceeded in bad faith to make their claim for compensation with respect to it. The second question is, if so, who was in on the deception? In particular, was the prime minister, Harold Macmillan, whom Kennedy compensated so generously for the Skybolt cancellation, in on it?

To raise such a question is to conjecture about whether the AngloAmerican relationship was not more competitive, more manipulative, more guileful than Neustadt depicts it to have been. That conjecture, if true, supports the suspicion that Macmillan played 
Kennedy for a fool at the Nassau Conference, a thought that occurred to some of Kennedy's subordinates. That possibility would not be incompatible with Neustadt's conception of Anglo-American relations, but it would require a fuller description of it. To have dealt with this harder side of a close bilateral relationship would have enabled Neustadt to put into sharper focus the presidential role in terms comparable to central themes in Presidential Politics which give greater weight to conflict in politics.

One objective of this book is to place "alliance politics" in the context of presidential leadership and power politics. Chapter 3 deals with an "alliance politics" relationship with India during the Johnson administration, a relationship that might have been handled in that chapter much as Neustadt dealt with Anglo-American relations, particularly with reference to the Skybolt affair. But it is not. It is treated quite differently. In Chapter 3, while the parallel interests and ongoing dealings of the Indo-United States bilateral relationship are acknowledged, the roots of conflict in the relationship are given serious attention and the utility of Johnson's hard stand with the Indians receives extended attention.

Writing Alliance Politics was an occasion for Neustadt to reflect on what he had learned about presidential politics on assignment for Kennedy. It was also an opportunity for him to go back to historical information about Eisenhower and examine more fully presidential leadership in the conduct of foreign relations during the crisis caused by the Suez War in 1956, with particular attention to the protection and enhancement of presidential power. In both cases he chose not to. The Neustadt of Alliance Politics avoided the harder side of Anglo-American relations in order to take up a task which he was not uniquely qualified to perform, to apply to AngloAmerican relations a pluralist model that minimized the difference between the president and his own staff, and minimized the significance of presidential leadership. Neustadt directed his attention chiefly to the level below the presidency, which enabled him to do this. It must be said that he employed great skill in presenting what he observed, that relations at that level between two close allies are like relations between great federal agencies in Washington. ${ }^{6}$ The big difference was that he did not pursue the hard questions that he had dealt with at length in Presidential Power, such as how presidents generated and managed conflicts to achieve their own ends.

Neustadt's Alliance Politics has been one of the more influential studies of American foreign relations of recent decades. Noting what he chose not to do in it can scarcely detract from its much-deserved reputation. Noting as I have what he chose not to do serves to indi- 
cate what happened on a larger landscape to attitudes about presidential leadership during the decade of the sixties. By I970, when Neustadt wrote Alliance Politics, he was not alone in demonstrating a loss of confidence and therefore of interest in presidential leadership. The attack on the "imperial presidency" was well underway.

For his part, as mentioned earlier, Neustadt, in ending Alliance Politics, explained his attachment to foreign policy pluralism to the neglect of the power and politics of the external presidency. His assignment from Kennedy had been to look into why the Skybolt affair had caused so much trouble between the British and the Americans. It had resulted in a written report to Kennedy. Neustadt explains that when he sent it to Kennedy he also asked for an appointment with the president so that he could extend his report by conveying lessons learned, which he preferred not to write down, about the way the machinery of the U.S. government worked in relationship to that of an ally. Kennedy agreed, but the meeting never took place because of his death. "One of the things" Neustadt considered raising with Kennedy while he anticipated the meeting "lay outside of my assignment, to say nothing of my field of observation: I considered asking whether, in the light of our machine's performance on a British problem, he conceived that it could cope with South Vietnam's." Writing in I970, Neustadt did not claim that he would have certainly raised it. "But it was a good question, better than I knew. It haunts me still." 7

The present study was written during a period of returning acceptance of presidential power exercised in foreign relations. In practice, this trend is associated with Presidents Reagan and Bush. In Reagan's case it reflected his success as a popular politician and his sometimes surprising and not always wise or even constitutional exercise of presidential initiative in foreign affairs. In Bush's case it reflects his perceived success, or luck, in dealing with the Soviet Union and the Middle East. Serious reflection about the exercise of presidential power in foreign relations which credits its potential uses as well as its dangers has been notably scarce during the past decade. Two strands of scholarship have some potential for this purpose. One, in the field of international relations theory, deals with the issue of national power as it is manifest in the phenomenon of superpower leadership, specifically of American hegemony. This subject will be discussed in Chapter 7 . The other deals with presidential power itself, in the person of President Eisenhower.

The revisionist literature on Eisenhower tells us that he was a better president than we thought. With respect to foreign relations, John Burke and Fred Greenstein explain that he was better because 
he took seriously the structure of the presidency, which is to say, the National Security Council and its elements in particular. He employed procedures which made use of this structural asset and which they claim enabled him to be more discriminating than some later presidents have been in choosing what to avoid and what to deal with as president and what to involve the nation in. ${ }^{8}$

The Eisenhower revisionists have identified but they have not examined diligently the central question of initiative-taking in foreign relations by the U.S. president as leader of the leading national power. That, I believe, is the challenge that Neustadt laid down for students of foreign relations, especially those students who are interested in the holistic presidency, which combines political leadership with management and administration. It is this challenge which this book seeks to clarify.

The most acute problem which this combination poses with respect to the presidency in foreign relations is in knowing with sufficient precision and reliability what the foreign or external effects of governmental action-and presidential action in particular-will be. We do not even know with any precision what attributes of presidential action promote what sorts of desirable outcomes in foreign relations. We know something about what kinds of presidential action promote what kinds of U.S. governmental outputs, although the lessons of Neustadt's Alliance Politics and related works on governmental processes strongly qualify our conclusions even about this matter, just as, with respect to internal policy, implementation is often full of surprises. ${ }^{9}$ Reflecting this situation, the present study devotes most of its attention to examining presidential action /and inaction) in relationship to their consequences for foreign relations. Its major purpose is to develop explanations that link internal organizational processes with their external effects or consequences.

This book proceeds at two levels. Chapter I launches it as administrative history. On this level the goal is modest, to provide a brief general account of how the Johnson administration organized to make foreign policy and conduct foreign relations and to explore structural issues further in the particular cases that follow. Chapter 2 begins a more ambitious inquiry, to define the issues of the presidential control and management of foreign relations through the experience of the Johnson administration. It is on this second level that the issues of the president's political leadership and power are considered.

As administrative history, it must be said, no attempt has been made in this study to be comprehensively descriptive. Chapter I provides a brief description of personnel and structure. After that I 
turn to the main issues of description and explanation-the "how" and "why" of the Johnson administration's foreign policy processby examining three subject areas. The first deals with foreign aid and relations with developing countries, which I address through a case study dealing with Johnson's handling of the Indian food crisis of I965-I967. The second deals with U.S. military cooperation with Western Europe, which I address through a case study about the American proposal for a multilateral nuclear force for NATO, called the MLF. These may be considered case studies. They provide intensive descriptions of organizational processes at the level of presidential action. They then serve as the basis for generalizations and explanations which depend also on other information, mainly about Johnson's foreign policy. In this way, the study seeks to strengthen the empirical basis for theories about the presidential management of foreign policy in general and about Johnson's management of foreign policy in particular.

The third subject, which in certain respects is also treated as a case study, deals with Johnson's handling of American policy toward Vietnam. The subject itself may be regarded as much larger than the subjects covered by the other two cases, if size can in this respect be considered an objective fact. If so, the space devoted to it bears no relationship to its size. It is therefore even more conspicuously selective in what it deals with in order to achieve a descriptive intensity that can serve as the basis for confident observations. It focuses on Johnson's Vietnam decisions during the period from the presidential election of November 1964 through July 1965 , ending with what amounted to a decision to commit the United States to a large-scale land war in Vietnam.

The reader should be aware of a progression in the employment of cases which occurs in this volume. Chapter 3 deals with the Indian case. The Indian case is composed of the most original historical work of the three case studies. To construct the Indian case I relied heavily on primary sources-documentation found primarily at the Johnson Library in Austin. This is not to say that I have been first in virgin territory. I have in fact made much use of previous work, particularly the excellent scholarship of James W. Bjorkland and of his mentors, Professors Lloyd I. Rudolph and Susanne H. Rudolph.

Chapters 4 and 5 deal with the MLF and Chapter 6 with Vietnam. I chose the MLF precisely because the territory was not virginbecause strong work, on which I knew I could rely, had already been done on it, mainly an excellent case study by John Steinbruner. ${ }^{10}$ Here, the objective has been to push further in a quite different context the ideas developed in connection with the Indian case. 
The "different context" is, of course, American relations with Western Europe, especially through the structure of NATO. In a sense, NATO is the parallel to Vietnam. Both are major components of Johnson's foreign policy. Viewed in these terms, the handling of the MLF proposal parallels with respect to Vietnam Johnson's November 1964 through July 1965 decisions. Both the MLF episode and these Vietnam decisions are revealing parts of larger foreign relations.

There is more observation and less description in the MLF chapters $(4$ and 5$)$, and the ratio shifts further in the Vietnam chapter (Chapter 6). The Vietnam chapter takes advantage of the fine scholarship that is now available on this difficult subject.

The last chapter returns to broader themes about presidential power. Noting that some of the harsher judgments about Johnson's management of foreign relations have moderated over time, and arguing that some of the remaining criticisms deal with him as though he should have acted like a judicious clerk, I note that behind much criticism, and behind the moderating of it, stand differences about how presidents should behave, particularly differences which deal with how presidents use their power as president and the power of the United States as a superpower. In earlier chapters I have not hesitated to draw out observations about the exercise of presidential power. Here, by way of conclusion, is my final attempt to deal with the interrupted theme of Richard Neustadt's Presidential Power.

So much for these anticipations. 
THIS PAGE INTENTIONALLY LEFT BLANK 